\title{
The Job Satisfaction Level of the Administrators Working at the Kindergartens Located in the Central Province of Jordan
}

\author{
Dr. Ibrahim Ali Al-Baher Dr. Ahlam Jum’a
}

\begin{abstract}
The present study aimed to explore the job satisfaction level of the administrators working at the kindergartens located in the central province of Jordan. A questionnaire was developed. 250 questionnaire forms were distributed to administrators working at the kindergartens located in the central province of Jordan. 220 forms were retrieved and considered valid for analysis. The sample was selected through using the random stratified sampling method. A descriptive survey-based approach was adopted. The validity and reliability of the questionnaire were measured. It was found that the job satisfaction level of the selected administrators is moderate. It was found that there is a statistically significant difference -at the statistical significance level of ( $a \leq 0.05)$ - between the respondents' job satisfaction levels which can be attributed to gender and academic qualification. The gender-related difference is for the favor of females. It was found that there isn't any are statistically significant difference -at the statistical significance level of $(\mathrm{a} \leq 0.05)$ - between the respondents' job satisfaction levels which can be attributed to experience. The researchers recommend exerting more effort to promote job satisfaction among the staff working at kindergartens. Such effort should be exerted by the Jordanian Ministry of Education. Such effort may include conducting studies about the social, economic, and psychological problems experienced by those administrators
\end{abstract} Keywords: Job satisfaction, kindergartens

DOI: $10.7176 / \mathrm{JEP} / 11-9-14$

Publication date:March $31^{\text {st }} 2020$

Introduction:

The kindergarten stage is considered a very important educational stage. That's because the provision of attention to kindergarten students shall significantly affect the development of the future generation. Thus, that shall significantly affect the development of the state. Due to the significant role of kindergartens, kindergartens must have a wise administration. Such administration must be capable of planning, organizing, guiding and leading staff effectively. They must seek providing the children with expertise in various areas of life. Providing children with such expertise plays a significant role in developing the children's personalities. It positively affect the developmental characteristics of children.

Each kindergartens has its own goals and policies. In order for kindergartens to achieve success and meet their goals, they must have an effective and wise administration. Such administration must exert efforts in order for employees to work effectively and efficiently. They must exert efforts in order for employees and administrators to enjoy a high job satisfaction level. In other words, it should be noted that the administration performance of any institution is the key factor affecting its success. In addition, the administration performance affects the survival of the institution.

Job satisfaction has been providing much attention by the scholars who are specialized in the field of administration and human behavior. Such attention has been provided due to having a significant relationship between employees' job satisfaction and productivity levels. In addition, having a high job satisfaction level shall make the employee motivated to work in an ongoing manner. When having a high job satisfaction level, the employee shall seek avoiding the commitment of mistakes while doing work tasks. Having a high job satisfaction level shall make the employee experience a high social and psychological adjustment.

Job satisfaction is affected by several factors. Such factors shall affect the employee's behavior at the workplace. They may include: experience, academic qualification and gender. Each gender is associated with specific psychological and physiological features. Such factors may include: factors related to the workplace environment, such as: the nature of the decisions he/she makes and the way of making these decisions. They may include: the extent of attention provided to the employee. Such attention may include: the training, and development courses provided to the employee. It may include: the moral and financial incentives provided to the employee. Incentives are given to the employee due to exerting a distinguished effort or making a distinguished achievement.

Many researchers suggest that it's significant to conduct studies about job satisfaction and its dimensions in institutions. That is because conducting such studies shall enable institutions to develop effective policies and overcome the shortcomings. In addition, conducting such studies shall enable institutions to improve the psychological health of the employees. It shall enable institutions to meet their goals, and meet its needs and the employees' needs (Hamshari, 2010). In this regard, it is necessary to identify the term (job satisfaction). Job satisfaction refers to the extent of the employee's contentedness with his/her job and extent of experiencing job stability and pleasure towards the things he/she has achieved at the workplace (Al-Anzi, 2009). 
Statement of the Problem

All educational institutions seek making their employees enjoy the highest job satisfaction level. That is because enjoying a high job satisfaction level shall positively affect the productivity and performance efficiency and effectiveness. In addition, enjoying a high job satisfaction level shall promote positive interaction among employees. It shall promote collaboration when doing the duties and tasks at work. When shedding a light on the kindergartens located in the central province of Jordan, there are several shortcomings in them. For instance, all the decisions made by the administration of those kindergartens are typical. In addition, the nature of the prevalent communication in these kindergartens is vertical. In addition, in these kindergartens, some employees aren't engaged in all the important activities and events. These kindergartens tend to carry out much complex and routine measures. Carrying out such measures shall negatively affect the nature of the employees' relationships with one another. In addition, several researchers suggest that the job satisfaction level of the administrators working at the kindergartens located in the central province of Jordan (Abu Taleb, 2000; Al-Harahsheh and Ahmad, 2013; and Al-Sharayri, 2007). In the light of that, the researchers of the present study aimed to explore the job satisfaction level of the administrators working at the kindergartens located in the central province of Jordan. To be more specific, they aimed to provide answers to the following questions:

Q.1: What is the extent of the job satisfaction level of the administrators working at the kindergartens located in the central province of Jordan?

Q.2: Is there any statistically significant difference -at the statistical significance level of $(\mathrm{a} \leq 0.05)$ - between the respondents' job satisfaction levels which can be attributed to gender, academic qualification or experience?

The Study's Significance:

This study's significance is listed below:

- Theoretical significance: The present study provides researchers with a theoretical framework about job satisfaction and the way of raising it

- Practical significance: The present study enables decision makers and policy makers at the Jordanian Ministry of Education to make decisions and develop policies that shall promote loyalty and belonging among the administrators working at the kindergartens located in Jordan. It enables those decision makers and policy makers to make decisions and develop policies that shall meet the goals of the Jordanian Ministry of Education. It shall enables those decision makers and policy makers to make decisions and develop policies for enforcing control over the staff at the kindergartens located in Jordan.

The Study's Terms:

The definitions of the study's terms are listed below

-Job satisfaction: It refers to experiencing job stability and security by the employee and having contentedness with the job (Al-Taweel, 2006)

Kindergartens: They refer to educational social institutions. The children whose age is within the range of (3-6) years enroll in these institutions. These institutions aim at developing the child's personality in all areas. They have well-planned educational programs (Sawalha, 2006).

The Study's Limits:

The study's limits are listed below

Human limits: The present study targets the administrators working at the kindergartens located in the central province of Jordan.

Temporal limits: The present study was conducted during the academic year (2019/2018).

Spatial limits: The present study was conducted in the kindergartens located in the central province of Jordan.

Previous Studies

Through this part, the researchers presented the relevant studies that are conducted in English and the ones that are conducted in Arabic language.

Bogler and Ronit (2001) aimed to explore the impact of the leadership style on teachers' job satisfaction level. The sample consists from 745 teachers who work at the Northern Province of Palestine. A questionnaire was used for collecting the relevant data. It was found that (teachers' perception for their profession, autonomy at work and self-esteem) significantly affect the teachers' job satisfaction level. It was found that most teachers perceive their profession as an important profession. It was found that there is a positive relationship between teachers' attitudes towards their profession and their job satisfaction level.

Jiang (2005) aimed to explore the impact of job satisfaction on several variables in China. The sample consists from 317 teachers who were selected from 21 kindergartens in Chinghai, China. It was found that organizational climate shall significantly affect the job satisfaction level of those teachers. It was found that the engagement in making reforms to the curricula shall significantly affect the job satisfaction among teachers. It was found that job satisfaction significantly affect the professional commitment, autonomy and burnout level of those teachers.

Sawalha (2006) aimed to explore whether there is any significant difference between the female kindergarten teachers' job satisfaction levels which can be attributed to salary, marital status, academic qualification, experience, or type of kindergarten. The sample consists from 85 kindergarten teachers who were selected from Jordan. A fifty 
nine item questionnaire was used for measuring the teachers' job satisfaction level. It was found that there is a significant difference between the female kindergarten teachers' job satisfaction levels which can be attributed to salary. The latter difference is for the favor of the teachers who earn more than 100 JDs per month. It was found that there is a significant difference between the female kindergarten teachers' job satisfaction levels which can be attributed to marital status. The latter difference is for the favor of the teachers who are married.

It was found that there is a significant difference between the female kindergarten teachers' job satisfaction levels which can be attributed to the academic qualification. The latter difference is for the favor of the teachers who hold diploma degree. It was found that there is a significant difference between the female kindergarten teachers' job satisfaction levels which can be attributed to experience. The latter difference is for the favor of the teachers who have much experience. It was found that there is a significant difference between the female kindergarten teachers' job satisfaction levels which can be attributed to the type of kindergarten. The latter difference is for the favor of the teachers who work in private kindergartens.

Al-Anzi (2009) aimed to explore the job satisfaction level of the female kindergarten teachers who work in Saudi Arabia. The sample consists from 61 female teachers who work in kindergartens located in Hafer Al-Baten, Saudi Arabia. To meet the study's goals, a fifty one item questionnaire was developed. It was found that the job satisfaction level of female kindergarten teachers in Hafer Al-Baten, Saudi Arabia is high. It was found that there is a significant difference between the female kindergarten teachers' job satisfaction levels which can be attributed to experience. The latter difference is for the favor of the teachers who have five years of experience or more. It was found that there isn't any significant difference between the female kindergarten teachers' job satisfaction levels which can be attributed to academic qualification.

Al-Habet (2013) aimed to explore the job satisfaction level of the female teachers who work in the public and private kindergartens located in Al-Qaseem, Saudi Arabia. The sample consists from 48 female teachers. A descriptive analytical approach was adopted. It was found that the job satisfaction level of the female teachers who work in the public and private kindergartens located in Al-Qaseem, Saudi Arabia is high.

Al-Harahsheh and Ahmad (2013) aimed to explore the problems facing the administration of the kindergartens located in Mafraq, Jordan from the perspective of the female employees. The sample consists from 82 employees. To meet the study's goals, thirty eight item questionnaire was used for collecting data. It was found that the severity of the problems facing the kindergartens located in Mafraq, Jordan is moderate from the perspective of the employees.

E'laimat and Aqil (2014) aimed to explore the job satisfaction level of the female teachers who work in the public kindergartens located in the central province in Jordan. The sample consists from 350 female teachers who work in the public kindergartens located in the central province in Jordan. To meet the study's goals, thirty eight item questionnaire was used for collecting data. It was found that the respondents' job satisfaction level is moderate. It was found that there is a significant difference between the female kindergarten teachers' job satisfaction levels which can be attributed to experience. The latter difference is for the favor of the teachers who have ten years of experience or more. It was found that there isn't any significant difference between the female kindergarten teachers' job satisfaction levels which can be attributed to academic qualification. It was found that there is a significant correlation between job satisfaction from one hand and (salary, incentives, nature of work, relationship with the boss, social status and prestige).

Haybah (2016) aimed to explore the job satisfaction level of female kindergarten teachers in Al-Madeenah AlMunawarah, Saudi Arabia. He aimed to explore whether there is any significant difference between the female kindergarten teachers' job satisfaction levels which can be attributed to academic qualification, experience, or type of kindergarten. A descriptive approach was adopted through analyzing the relevant studies. The sample consists from 200 female kindergarten teachers. It was found that the female kindergarten teachers' job satisfaction is high in several areas. These areas include: (administration, social relationships, work nature, professional development and workplace environment). It was found that the female kindergarten teachers' satisfaction with the financial incentives is moderate.

The difference between the present study and the aforementioned studies:

Reviewing the approach, statistical methods, theoretical framework, and variables of the aforementioned studies assisted the researchers in conducting the present study. Reviewing the studies conducted by E'laimat and Aqil (2014) and (Al-Anzi, 2009) assisted the researchers in developing the study's instrument. There are similarities between the present study and the studies conducted by Al-Harahsheh and Ahmad (2013) and Sawalha (2006) in terms of the examined variables. To be specific, similar to the present study, the studies of Al-Harahsheh and Ahmad (2013) and Sawalha (2006) aimed to shed a light on academic qualification and experience. However, the present study differs from the aforementioned studies because it sheds a light on the job satisfaction level of the administrators working at the kindergartens located in the central province of Jordan. It differs from the aforementioned studies because none of those studies shed a light on gender, academic qualification and experience jointly. 
Methods and Procedures:

To meet the study's goals, the researchers adopted a descriptive survey-based approach

The Study's Population:

The study's population consists from all the administrators working at the kindergartens located in the central province of Jordan. To be more specific, the population consists from 1145 administrators working at the kindergartens located in the central province of Jordan. Table (1) shows the distribution of the study's population. Table (1): The distribution of the study's population in accordance with gender, academic qualification or experience

\begin{tabular}{|c|c|c|c|}
\hline Variable & Category & Frequency & Total \\
\hline \multirow[t]{2}{*}{ Gender } & Male & 135 & \multirow[t]{2}{*}{1145} \\
\hline & Female & 920 & \\
\hline \multirow[t]{4}{*}{ Academic qualification } & Postgraduate degree & 123 & \multirow{4}{*}{1145} \\
\hline & BA degree & 286 & \\
\hline & Diploma degree & 676 & \\
\hline & Secondary school certificate & 115 & \\
\hline \multirow[t]{2}{*}{ Years of experience } & Five years or less & 869 & \multirow[t]{2}{*}{1145} \\
\hline & More than five years & 276 & \\
\hline
\end{tabular}

*Source: The records of the Jordanian Ministry of Education

The Study's Sample:

The researchers selected the number of the sampled teachers based on the equation developed by Stephen Thompson. The random stratified sampling method. The statistical significance level is $(\mathrm{a} \leq 0.05)$. The researchers selected 250 administrators working at the kindergartens located in the central province of Jordan. Questionnaire forms were distributed to those administrators. 220 forms were retrieved and analyzed. Table (2) presents data about the selected sample:

Table (2): The distribution of the selected sample in accordance with specific variables

\begin{tabular}{|l|l|r|r|}
\hline Variable & Category & Frequency & Total \\
\hline \multirow{3}{*}{ Gender } & Male & $\mathbf{5 7}$ & $\mathbf{2 5 0}$ \\
\cline { 2 - 3 } & Female & $\mathbf{1 9 3}$ & \\
\hline Academic qualification & Postgraduate degree & $\mathbf{1 8}$ & $\mathbf{2 5 0}$ \\
\cline { 2 - 3 } & BA & $\mathbf{3 2}$ \\
\cline { 2 - 3 } & Diploma & $\mathbf{1 1 4}$ \\
\cline { 2 - 3 } & Secondary school certificate & $\mathbf{8 6}$ & $\mathbf{1 8 6}$ \\
\hline Years of experience & Five years or less & $\mathbf{6 4}$ & \\
\cline { 2 - 3 } & More than five years & 50 \\
\hline
\end{tabular}

The Study's Instrument

The researchers developed the study's instrument based on the relevant studies, such as the studies conducted by E'laimat and Aqil (2014) and Al-Anzi, (2009). The preliminary version of the questionnaire consists from 46 items. The final version of the questionnaire consists from 40 items. These items are shed a light on 4 areas. These areas are:

1) Decisions: There are 8 items that shed a light on this area

2) Technology: There are 8 items that shed a light on this area

3) Provision of attention to employees: There are 17 items that shed a light on this area

4) Incentives: There are 7 items that shed a light on this area

To measure the validity of the questionnaire, the preliminary version of the questionnaire was passed to experts in the field educational administration. Those experts were asked to assess the questionnaire in terms of language, relevancy and content. They were asked to made additions, deletions or changes to the questionnaire. In the light of the experts' opinions, the researchers made several adjustments. The final version of the questionnaire consists from 40 items.

To measure the reliability of the questionnaire, Cronbach Alpha coefficient values were calculated. These values are presented below in table (3)

Table (3): The Cronbach Alpha coefficient values

\begin{tabular}{|l|l|l|}
\hline No. & Area & Cronbach Alpha coefficient value \\
\hline & Decisions & 0.92 \\
\hline & Technology & 0.95 \\
\hline & Provision of attention to employees & 0.96 \\
\hline & Incentives & 0.92 \\
\hline
\end{tabular}

Based on table (3), the Cronbach Alpha coefficient values indicate that the instrument is very reliable. The following criteria were adopted to classify means: 


\subsection{3 or less: Low}

2.34-3.67: Moderate

3.68 or more: High

Results and discussion:

Results and discussion related to the first question:

Q.1: What is the extent of the job satisfaction level of the administrators working at the kindergartens located in the central province of Jordan?

To answer this question, the researchers calculated means and standard deviations for the areas jointly and separately. Table (4) presents these values.

Table (4): means and standard deviations for measuring the job satisfaction level of the administrators working at the kindergartens located in the central province of Jordan

\begin{tabular}{|c|c|c|c|c|c|}
\hline No. & Area & Mean & Std. & Rank & Level \\
\hline 2 & Decisions & 3.79 & 0.81 & 2 & High \\
\hline 4 & Technology & $\mathbf{3 . 5 5}$ & 0.91 & 3 & Moderate \\
\hline 1 & Provision of attention to employees & 3.55 & 0.91 & 3 & Moderate \\
\hline 3 & Incentives & 3.29 & 1.01 & 1 & Moderate \\
\hline & Total & 3.57 & 0.71 & Moderate & \\
\hline
\end{tabular}

Based on table (4), it can be noticed that the job satisfaction level of the administrators working at the kindergartens located in the central province of Jordan is moderate. That is because the total mean is 3.57 . The total standard deviation is 0.71 . The decisions area is ranked first because the relevant mean is 3.79 . The latter mean is high. The other areas show moderate means. The incentives area is ranked last, because the relevant mean is 3.29.

The detailed results about each area are presented below:

1)-The decisions area:

To explore the job satisfaction level of the respondents in the decisions area, means and standard deviations were calculated. Table (5) presents these means and standard deviations

Table (5): The means and standard deviations of the job satisfaction level of the respondents in the decisions area

\begin{tabular}{|c|c|c|c|c|c|}
\hline No. & Statement & Mean & Std. & Rank & Level \\
\hline 2 & $\begin{array}{l}\text { There is much mutual trust between administrators during the } \\
\text { decision making process }\end{array}$ & 3.92 & 1.01 & 1 & High \\
\hline 1 & $\begin{array}{l}\text { The decisions made by the administrators fit with the goals that the } \\
\text { kindergarten aims to achieve. }\end{array}$ & 3.90 & 0.84 & 2 & High \\
\hline 6 & $\begin{array}{l}\text { The administrators engage in developing the kindergarten } \\
\text { development plans }\end{array}$ & 3.80 & 1.02 & 3 & High \\
\hline 5 & $\begin{array}{l}\text { The administrators play a significant role in determining the } \\
\text { appropriate assessment methods to be used in courses }\end{array}$ & 3.77 & 0.98 & 4 & High \\
\hline 8 & $\begin{array}{l}\text { The decisions made by the kindergarten administration create } \\
\text { friendly relationships among the administrators }\end{array}$ & 3.75 & 1.01 & 5 & High \\
\hline 7 & The decisions made by the kindergarten administration are objective & 3.73 & 1.00 & 6 & High \\
\hline 3 & $\begin{array}{l}\text { The decisions are made by the kindergarten administration through } \\
\text { adopting the majority voting method }\end{array}$ & 3.71 & 1.00 & 6 & High \\
\hline 4 & $\begin{array}{l}\text { The administrators are given the opportunity to engage in the } \\
\text { process of making the decisions related to their work }\end{array}$ & 3.62 & 1.09 & 8 & Moderate \\
\hline & Total & 3.76 & 0.79 & & High \\
\hline
\end{tabular}

Based on table (5), it was found that the job satisfaction level of the respondents in the decisions area is high. That is because the total mean is 3.76 which is high. The total standard deviation is 0.79 . The means in table (5) are within the range of (3.92-3.62). The mean of statement (2) is 3.92. The latter mean is high and ranked first. Statement (2) states the following: (There is much mutual trust between administrators during the decision making process). The mean of statement (4) is 3.62. The latter mean is moderate and ranked last. Statement (4) states the following: (The administrators are given the opportunity to engage in the process of making the decisions related to their work). The researchers believe that administrators are given such an opportunity because they show a high level of intellectual maturity and productivity. They believe that administrators are given such an opportunity because they are highly capable of making achievement and handling responsibility.

2)-The technology area:

To explore the job satisfaction level of the respondents in the technology area, means and standard deviations were calculated. Table (6) presents these means and standard deviations 
Table (6): The means and standard deviations of the job satisfaction level of the respondents in the technology area

\begin{tabular}{|r|l|r|r|r|r|}
\hline No. & Statement & Mean & Std. & Rank & Level \\
\hline $\mathbf{1}$ & $\begin{array}{l}\text { The kindergarten administration is keen to keep up with the } \\
\text { technological developments }\end{array}$ & $\mathbf{3 . 6 3}$ & $\mathbf{1 . 1 0}$ & $\mathbf{1}$ & Moderate \\
\hline $\mathbf{6}$ & The computer programs used at the kindergarten are easy to use. & $\mathbf{3 . 6 0}$ & $\mathbf{1 . 0 6}$ & $\mathbf{2}$ & Moderate \\
\hline $\mathbf{7}$ & $\begin{array}{l}\text { The (data and information) available at the kindergarten can be } \\
\text { easily exchanged }\end{array}$ & $\mathbf{3 . 6 0}$ & $\mathbf{1 . 0 6}$ & $\mathbf{2}$ & Moderate \\
\hline $\mathbf{4}$ & $\begin{array}{l}\text { The technology used in the kindergarten enables the staff to carry } \\
\text { out work tasks quickly. }\end{array}$ & $\mathbf{3 . 5 7}$ & $\mathbf{1 . 1 0}$ & $\mathbf{4}$ & Moderate \\
\hline $\mathbf{8}$ & $\begin{array}{l}\text { The kindergarten administration is keen to address the } \\
\text { technological changes effectively in order to raising performance }\end{array}$ & $\mathbf{3 . 5 4}$ & $\mathbf{1 . 0 5}$ & $\mathbf{5}$ & Moderate \\
\hline $\mathbf{5}$ & $\begin{array}{l}\text { The technology used in the kindergarten plays a significant role in } \\
\text { raising the quality level of the services delivered to administrators. }\end{array}$ & $\mathbf{3 . 5 2}$ & $\mathbf{1 . 0 9}$ & $\mathbf{6}$ & Moderate \\
\hline $\mathbf{2}$ & $\begin{array}{l}\text { The kindergarten administration provides the staff with the needed } \\
\text { technology for carrying out the (educational and administrative) } \\
\text { tasks }\end{array}$ & $\mathbf{3 . 5 1}$ & $\mathbf{1 . 0 9}$ & $\mathbf{7}$ & Moderate \\
\hline $\mathbf{3}$ & $\begin{array}{l}\text { The technology used in the kindergarten fits with the nature of the } \\
\text { work requirements }\end{array}$ & $\mathbf{3 . 4 9}$ & $\mathbf{1 . 0 4}$ & $\mathbf{8}$ & Moderate \\
\hline & Total & $\mathbf{3 . 5 5}$ & $\mathbf{0 . 9 1}$ & & Moderate \\
\hline
\end{tabular}

Based on table (6), the job satisfaction level of the respondents in the technology area is moderate. That is because the relevant mean is 3.55. The total standard deviation is 1.04. The means in table (6) are within the range of (3.493.63). The mean of statement (1) is 3.63. The latter mean is moderate and ranked first. Statement (1) states the following: (The kindergarten administration is keen to keep up with the technological developments).

The mean of statement (3) is 3.49. The latter mean is moderate and ranked last. Statement (3) states the following: (The technology used in the kindergarten fits with the nature of the work requirements). The result of statement 3 may be attributed to the poor financial nature of kindergartens in acquiring the recent advanced technologies which fit with the nature of the work requirements. It may be attributed to the fact that the technologies used in kindergarten weren't replaced with new ones. That shall make employees incapable of meeting the work requirements and keeping up with the latest developments

3)-The provision of attention to employees

To explore the job satisfaction level of the respondents in the area of providing attention to employee, means and standard deviations were calculated. Table (7) presents these means and standard deviations

Table (7): The means and standard deviations of the job satisfaction level of the respondents in the area of providing attention to employee

\begin{tabular}{|r|l|r|r|r|r|}
\hline No. & Statement & Mean & Std. & Rank & Level \\
\hline $\mathbf{5}$ & $\begin{array}{l}\text { My colleagues who work as administrators in the kindergarten } \\
\text { appreciate the efforts that I exert }\end{array}$ & $\mathbf{3 . 8 2}$ & $\mathbf{0 . 9 5}$ & $\mathbf{1}$ & High \\
\hline $\mathbf{2}$ & $\begin{array}{l}\text { The kindergarten administration provides me with the opportunity } \\
\text { to participate effectively in the administration meetings }\end{array}$ & $\mathbf{3 . 7 9}$ & $\mathbf{1 . 0 4}$ & $\mathbf{2}$ & High \\
\hline $\mathbf{4}$ & The kindergarten administration appreciates the effort that I exert. & $\mathbf{3 . 7 0}$ & $\mathbf{1 . 1 4}$ & $\mathbf{3}$ & High \\
\hline $\mathbf{1 0}$ & $\begin{array}{l}\text { The control enforced by the kindergarten administration on } \\
\text { administrators is based on trust }\end{array}$ & $\mathbf{3 . 6 7}$ & $\mathbf{1 . 0 1}$ & $\mathbf{4}$ & Moderate \\
\hline $\mathbf{3}$ & $\begin{array}{l}\text { The kindergarten administration provides me with information } \\
\text { about what's going on in the kindergarten I am working at }\end{array}$ & $\mathbf{3 . 6 7}$ & $\mathbf{1 . 0 1}$ & $\mathbf{4}$ & Moderate \\
\hline $\mathbf{1 6}$ & $\begin{array}{l}\text { The kindergarten administration respect my opinion when making } \\
\text { a decision }\end{array}$ & $\mathbf{3 . 6 2}$ & $\mathbf{1 . 1 4}$ & $\mathbf{6}$ & Moderate \\
\hline $\mathbf{1}$ & $\begin{array}{l}\text { The kindergarten administration provides me with the opportunity } \\
\text { to participate in the ongoing development of the kindergarten }\end{array}$ & $\mathbf{3 . 6 0}$ & $\mathbf{1 . 0 9}$ & $\mathbf{7}$ & Moderate \\
\hline $\mathbf{1 1}$ & $\begin{array}{l}\text { The administrators in the kindergarten are assessed based on the } \\
\text { same criteria }\end{array}$ & $\mathbf{3 . 5 9}$ & $\mathbf{1 . 1 3}$ & $\mathbf{8}$ & Moderate \\
\hline $\mathbf{1 4}$ & The kindergarten administration is keen to retain administrators & $\mathbf{3 . 5 8}$ & $\mathbf{1 . 1 4}$ & $\mathbf{9}$ & Moderate \\
\hline $\mathbf{1 3}$ & $\begin{array}{l}\text { The kindergarten administration provides me with the opportunity } \\
\text { to participate in (courses, conferences and symposium) }\end{array}$ & $\mathbf{3 . 5 7}$ & $\mathbf{1 . 2 2}$ & $\mathbf{1 0}$ & Moderate \\
\hline $\mathbf{6}$ & $\begin{array}{l}\text { I am satisfied with the opportunities that I am provided with for } \\
\text { doing my administrative tasks }\end{array}$ & $\mathbf{3 . 5 5}$ & $\mathbf{1 . 1 9}$ & $\mathbf{1 1}$ & Moderate \\
\hline $\mathbf{1 5}$ & $\begin{array}{l}\text { I feel that there is much fairness in the kindergarten I work at } \\
\mathbf{n}\end{array}$ & $\mathbf{3 . 5 2}$ & $\mathbf{1 . 2 1}$ & $\mathbf{1 2}$ & Moderate \\
\hline
\end{tabular}




\begin{tabular}{|r|l|r|r|r|r|}
\hline No. & Statement & Mean & Std. & Rank & Level \\
\hline $\mathbf{1 7}$ & $\begin{array}{l}\text { The kindergarten administration seek developing the } \\
\text { administrative capabilities of administrators in an ongoing manner }\end{array}$ & $\mathbf{3 . 4 8}$ & $\mathbf{1 . 1 1}$ & $\mathbf{1 3}$ & Moderate \\
\hline $\mathbf{9}$ & $\begin{array}{l}\text { The kindergarten administration may provide me with assistance } \\
\text { when there is too much workload. }\end{array}$ & $\mathbf{3 . 4 6}$ & $\mathbf{1 . 1 2}$ & $\mathbf{1 4}$ & Moderate \\
\hline $\mathbf{8}$ & $\begin{array}{l}\text { The workplace environment makes me feel safe and secure due to } \\
\text { the available equipment }\end{array}$ & $\mathbf{3 . 3 5}$ & $\mathbf{1 . 1 5}$ & $\mathbf{1 5}$ & Moderate \\
\hline $\mathbf{1 2}$ & $\begin{array}{l}\text { The kindergarten administration meets my ambitions, and } \\
\text { aspirations for improving my capabilities }\end{array}$ & $\mathbf{3 . 3 2}$ & $\mathbf{1 . 2 0}$ & $\mathbf{1 6}$ & Moderate \\
\hline $\mathbf{7}$ & $\begin{array}{l}\text { I am satisfied with the benefits that I receive for improving my } \\
\text { living conditions }\end{array}$ & $\mathbf{3 . 1 7}$ & $\mathbf{1 . 3 0}$ & $\mathbf{1 7}$ & Moderate \\
\hline & Total & $\mathbf{3 . 5 5}$ & $\mathbf{0 . 9 0}$ & & Moderate \\
\hline
\end{tabular}

Based on table (7), the job satisfaction level of the respondents in the area of providing attention to employee is moderate. That is because the total mean is 3.55 . The total standard deviation is 0.90 . The mean of statement (5) is 3.82. The latter mean is high and ranked first. Statement (5) states the following: (My colleagues who work as administrators in the kindergarten appreciate the efforts that I exert). The mean of statement (7) is 3.17. The latter mean is moderate and ranked last. Statement (7) states the following: (I am satisfied with the benefits that I receive for improving my living conditions).

The moderate satisfaction with the benefits may be attributed to the poor attention provided to the development of the administrative process. It may be attributed to the poor capability of the kindergarten administration to provide benefits that can meet the ambitions of the administrators. It may be attributed to the fact that administrators have high ambitions that do not fit with the resources at the kindergarten.

4)-The incentives area:

To explore the job satisfaction level of the respondents in the incentives area, means and standard deviations were calculated. Table (8) presents these means and standard deviations

Table (8): The means and standard deviations of the job satisfaction level of the respondents in the incentives area

\begin{tabular}{|r|l|r|r|r|r|}
\hline No. & Statement & Mean & Std. & Rank & Level \\
\hline $\mathbf{1}$ & The moral incentives encourage me to raise my performance level & $\mathbf{3 . 5 7}$ & $\mathbf{1 . 2 5}$ & $\mathbf{1}$ & Moderate \\
\hline $\mathbf{3}$ & $\begin{array}{l}\text { The organizational climate of the kindergarten I work at is full of } \\
\text { optimism and security }\end{array}$ & $\mathbf{3 . 5 3}$ & $\mathbf{1 . 1 9}$ & $\mathbf{2}$ & Moderate \\
& $\begin{array}{l}\text { The financial incentives encourage me to raise my performance } \\
\text { level }\end{array}$ & $\mathbf{3 . 3 5}$ & $\mathbf{1 . 2 9}$ & $\mathbf{3}$ & Moderate \\
\hline $\mathbf{7}$ & $\begin{array}{l}\text { The incentives provided by the kindergarten administration promote } \\
\text { organizational loyalty among the administrators }\end{array}$ & $\mathbf{3 . 2 7}$ & $\mathbf{1 . 1 9}$ & $\mathbf{4}$ & Moderate \\
\hline $\mathbf{5}$ & $\begin{array}{l}\text { When the kindergarten administration gives rewards, it takes into } \\
\text { consideration the work load }\end{array}$ & $\mathbf{3 . 2 3}$ & $\mathbf{1 . 1 5}$ & $\mathbf{5}$ & Moderate \\
\hline $\mathbf{4}$ & $\begin{array}{l}\text { In the kindergarten I work at, the ones who show a distinguished } \\
\text { performance are provide with rewards }\end{array}$ & $\mathbf{3 . 0 8}$ & $\mathbf{1 . 2 4}$ & $\mathbf{6}$ & Moderate \\
\hline $\mathbf{6}$ & $\begin{array}{l}\text { The kindergarten administration encourages administrators to } \\
\text { propose new incentives systems }\end{array}$ & $\mathbf{3 . 0 2}$ & $\mathbf{1 . 2 3}$ & $\mathbf{7}$ & Moderate \\
\hline & Total & $\mathbf{3 . 2 9}$ & $\mathbf{1 . 0 1}$ & & Moderate \\
\hline
\end{tabular}

Based on table (8), the job satisfaction level of the respondents in the incentives area is moderate. That is because the total mean is 3.29. The total standard deviation is 1.01. The mean of statement (1) is 3.57. The latter mean is moderate and ranked first. Statement (1) states the following: (The moral incentives encourage me to raise my performance level). The mean of statement (6) is 3.02. The latter mean is moderate and ranked last. Statement (6) states the following: (The kindergarten administration encourages administrators to propose new incentives systems). The latter result indicates that the kindergarten administration highly believes that the existent incentives systems are effective and capable of meeting the administrators' needs.

Results and Discussion related to the Second Question:

Q.2: Is there any statistically significant difference -at the statistical significance level of $(\mathrm{a} \leq 0.05)$ - between the respondents' job satisfaction levels which can be attributed to gender, academic qualification or experience?

The answer of this question is presented below in details:

A)-Results related to Gender:

Means and standard deviations are calculated. The t-test was conducted. Table (9) presents the results of the t-test below 
Table (9): The results of the t-test for identifying the results related to gender

\begin{tabular}{|c|c|c|c|c|c|c|}
\hline Area & Gender & Frequency & Mean & Std. & T value & Sig. \\
\hline \multirow[t]{3}{*}{ Decisions } & Female & 186 & 3.86 & 0.77 & 2.745 & $* * 0.006$ \\
\hline & Male & 34 & 3.61 & 0.86 & & \\
\hline & Total & 220 & 3.73 & 0.81 & & \\
\hline \multirow[t]{3}{*}{ Technology } & Female & 186 & 3.58 & 0.92 & 0.892 & 0.373 \\
\hline & Male & 34 & 3.49 & 0.91 & & \\
\hline & Total & 220 & 3.53 & 0.91 & & \\
\hline \multirow{3}{*}{$\begin{array}{ll}\text { Provision of } \\
\text { attention } & \text { to } \\
\text { employees } & \\
\end{array}$} & Female & 186 & 3.65 & 0.89 & 3.349 & $* * 0.001$ \\
\hline & Male & 34 & 3.31 & 0.89 & & \\
\hline & Total & 220 & 3.48 & 0.89 & & \\
\hline \multirow[t]{3}{*}{ Incentives } & Female & 186 & 3.36 & 1.02 & 2.152 & $* * 0.032$ \\
\hline & Male & 34 & 3.12 & 0.98 & & \\
\hline & Total & 220 & 3.36 & 1.00 & & \\
\hline \multirow[t]{3}{*}{ Total } & Female & 186 & 3.63 & 0.82 & 2.559 & $* * 0.011$ \\
\hline & Male & 34 & 3.43 & 0.83 & & \\
\hline & Total & 220 & 3.53 & 1.65 & & \\
\hline
\end{tabular}

(**): This sign means that the value is statistically significant at the statistical significance level is $(\mathrm{a} \leq 0.05)$ -

To identify whether there is any statistically significant difference -at the statistical significance level of $(\mathrm{a} \leq 0.05)$ between the respondents' job satisfaction level which can be attributed to gender, the t-test was conducted. Based on table (9), there is a statistically significant difference -at the statistical significance level of $(\mathrm{a} \leq 0.05)$-between the respondents' job satisfaction level which can be attributed to gender. That is because the calculated t value is 2.559 and the significance value is 0.011 . The latter difference is for the favor of female respondents. That means that female administrators show a higher job satisfaction level than male administrators in the selected kindergartens. It may be attributed to the fact that females are more capable than males to identify the needs of the kindergarten children. Due to such capability, females are given more opportunities to engage in the decision making process. That shall make female administrators more satisfied.

It was found that there is a statistically significant difference -at the statistical significance level of $(\mathrm{a} \leq 0.05)$ between the respondents' job satisfaction level which can be attributed to gender in the incentives area. It was found that there isn't any statistically significant difference -at the statistical significance level of $(\mathrm{a} \leq 0.05)$ between the respondents' job satisfaction level which can be attributed to gender in the technology area. That indicates that male and female respondents have similar attitudes towards the extent of availability of technologies in kindergartens

B)-Results related to experience

Means and standard deviations are calculated. The t-test was conducted. Table (10) presents the results of the ttest below

Table (10): The results of the t-test for identifying the results related to experience

\begin{tabular}{|c|c|c|c|c|c|c|}
\hline Area & Experience & Frequency & Mean & Std. & T value & Sig. \\
\hline \multirow[t]{3}{*}{ Decisions } & Five years or less & 169 & 3.73 & 0.77 & -1.777 & 0.076 \\
\hline & More than five years & 51 & 3.88 & 0.86 & & \\
\hline & Total & 220 & 3.80 & 0.81 & & \\
\hline \multirow[t]{3}{*}{ Technology } & Five years or less & 169 & 3.46 & 0.92 & -2.438 & $* * 0.015$ \\
\hline & More than five years & 51 & 3.69 & 0.91 & & \\
\hline & Total & 220 & 3.57 & 0.91 & & \\
\hline \multirow[t]{3}{*}{ Provision of attention to employees } & Five years or less & 169 & 3.52 & 0.89 & -0.757 & 0.449 \\
\hline & More than five years & 51 & 3.59 & 0.89 & & \\
\hline & Total & 220 & 3.55 & 0.89 & & \\
\hline \multirow[t]{3}{*}{ Incentives } & Five years or less & 169 & 3.29 & 1.02 & 0.059 & 0.953 \\
\hline & More than five years & 51 & 3.29 & 0.98 & & \\
\hline & Total & 220 & 3.29 & 1.00 & & \\
\hline \multirow[t]{3}{*}{ Total } & Five years or less & 169 & 3.53 & 1.64 & -1.284 & 0.200 \\
\hline & More than five years & 51 & 3.63 & 1.67 & & \\
\hline & Total & 220 & 3.58 & 1.65 & & \\
\hline
\end{tabular}

$(* *)$ : This sign means that the value is statistically significant at the statistical significance level is $(\mathrm{a} \leq 0.05)$

To identify whether there is any statistically significant difference -at the statistical significance level of $(a \leq 0.05)$ between the respondents' job satisfaction level which can be attributed to experience, the t-test was conducted. Based on table (10), there is a statistically significant difference -at the statistical significance level of $(a \leq 0.05)$ - 
between the respondents' job satisfaction level which can be attributed to experience. That is because the calculated $\mathrm{t}$ value is -1.284 and the significance value is 0.200 . The latter difference is for the favor of the ones who have five years or more of experience. That may be attributed to the facts that the ones who have five years or more of experience have more knowledge about the challenges facing administrators. Thus, much attention are provided to them.

B)-Results related to academic qualification

Means and standard deviations are calculated. Table (11) presents these values

Table (11): The results of the t-test for identifying the results related to academic qualification

\begin{tabular}{|c|c|c|c|c|}
\hline Area academic qualification & Category & Frequency & Mean & Std. \\
\hline \multirow[t]{5}{*}{ Decisions } & Postgraduate degree & 12 & 3.81 & 0.60 \\
\hline & BA degree & 24 & 3.90 & 0.89 \\
\hline & Diploma degree & 106 & 3.77 & 0.81 \\
\hline & Secondary school certificate & 78 & 3.67 & 0.80 \\
\hline & Total & 220 & 3.78 & 0.77 \\
\hline \multirow[t]{5}{*}{ Technology } & Postgraduate degree & 12 & 3.56 & 0.88 \\
\hline & BA degree & 24 & 3.69 & 0.92 \\
\hline & Diploma degree & 106 & 3.49 & 0.91 \\
\hline & Secondary school certificate & 78 & 3.57 & 0.96 \\
\hline & Total & 220 & 3.75 & 0.91 \\
\hline \multirow[t]{5}{*}{ Provision of attention to employees } & Postgraduate degree & 12 & 3.58 & 0.95 \\
\hline & BA degree & 24 & 3.67 & 0.96 \\
\hline & Diploma degree & 106 & 3.56 & 0.87 \\
\hline & Secondary school certificate & 78 & 3.33 & 0.86 \\
\hline & Total & 220 & 3.53 & 0.91 \\
\hline \multirow[t]{5}{*}{ Incentives } & Postgraduate degree & 12 & 3.33 & 1.09 \\
\hline & BA degree & 24 & 3.43 & 1.00 \\
\hline & Diploma degree & 106 & 3.29 & 0.98 \\
\hline & Secondary school certificate & 78 & 3.05 & 1.04 \\
\hline & Total & 220 & 3.27 & 1.02 \\
\hline \multirow[t]{5}{*}{ Total } & Postgraduate degree & 12 & 3.61 & 1.59 \\
\hline & BA degree & 24 & 3.69 & 1.73 \\
\hline & Diploma degree & 106 & 3.54 & 1.61 \\
\hline & Secondary school certificate & 78 & 3.46 & 0.84 \\
\hline & Total & 220 & 3.57 & 1.44 \\
\hline
\end{tabular}

Based on table (11), it appears that there are differences between the respondents' job satisfaction level which can be attributed to the academic qualification. In order to identify whether these differences are significant or not at the statistical significance level is $(\mathrm{a} \leq 0.05)$, the one-way analysis of variance was conducted. The results of the latter analysis are presented in table (12) below

Table (12): The results of the one way analysis of variance for exploring the statistical significance of the differences that can be attributed to academic qualification

\begin{tabular}{|c|c|c|c|c|c|c|}
\hline Area & $\begin{array}{cr}\text { Source } & \text { of } \\
\text { variance }\end{array}$ & $\begin{array}{rr}\text { Sum } & \begin{array}{r}\text { of } \\
\text { squares }\end{array} \\
\end{array}$ & df. & $\begin{array}{l}\text { Mean } \\
\text { square }\end{array}$ & $\begin{array}{r}\text { F } \\
\text { value } \\
\end{array}$ & Sig. \\
\hline \multirow[t]{3}{*}{ Decisions } & Between groups & 1.982 & 3 & 0.661 & 1.005 & 0.391 \\
\hline & Within groups & 305.594 & 349 & 0.572 & & \\
\hline & Total & 307.576 & 352 & & & \\
\hline \multirow[t]{3}{*}{ Technology } & Between groups & 2.295 & 3 & 0.765 & 0.906 & 0.438 \\
\hline & Within groups & 290.198 & 349 & 0.831 & & \\
\hline & Total & 292.493 & 352 & & & \\
\hline \multirow{3}{*}{$\begin{array}{l}\text { Provision of attention to } \\
\text { employees }\end{array}$} & Between groups & 4.496 & 3 & 1.499 & 1.829 & 0.141 \\
\hline & Within groups & 368.374 & 349 & 1.056 & & \\
\hline & Total & $\mathbf{3 7 2 . 8 7}$ & 352 & & & \\
\hline \multirow[t]{3}{*}{ Incentives } & Between groups & 5.069 & 3 & 1.690 & 1.646 & 0.178 \\
\hline & Within groups & 233.309 & 349 & 0.668 & & \\
\hline & Total & 238.378 & 352 & & & \\
\hline \multirow[t]{3}{*}{ Total } & Between groups & 3.076 & 3 & 0.316 & 0.633 & 0.56 \\
\hline & Within groups & 295.151 & 349 & 0.311 & & \\
\hline & Total & & 352 & & & \\
\hline
\end{tabular}


$(* *)$ : This sign means that the value is statistically significant at the statistical significance level is $(a \leq 0.05)$

Based on table (12), it was found that there is a statistically significant difference -at the statistical significance level of ( $\leq 0.05$ )-between the respondents' job satisfaction level which can be attributed to the academic qualification. That is because the calculated $\mathrm{F}$ value is 0.633 and the significance value is 0.56 . That may be attributed to the fact that administrators are highly concerned in incentives, financial gains, and collaboration in the decision making process. When conducting a comparison between the ones holding BA degree and the ones holding secondary school certificate, it can be concluded that the difference is for the favor of the ones holding BA degree in the decision area. When conducting a comparison between the ones holding BA degree and the ones holding a diploma, it can be concluded that the difference is for the favor of the ones holding BA in the technology area. When conducting a comparison between the ones holding BA degree and the ones holding a secondary school certification, it can be concluded that the difference is for the favor of the ones holding BA degree in the area of providing attention to employee. When conducting a comparison between the ones holding BA degree and the ones holding a secondary school certification, it can be concluded that the difference is for the favor of the ones holding BA degree in the incentives area

The scheffe test was conducted for identifying the ones whose the differences are for their favor. Table (13) presents the results of this test Table (13): The results of scheffe test for identifying the ones whose the differences are for their favor

\begin{tabular}{|c|c|c|c|c|c|c|}
\hline \multirow[t]{2}{*}{ Academic qualification } & \multirow[t]{2}{*}{ Mean } & $\begin{array}{r}\text { Postgraduate } \\
\text { degree }\end{array}$ & $\begin{array}{r}\text { BA } \\
\text { degree }\end{array}$ & $\begin{array}{r}\text { Diploma } \\
\text { degree }\end{array}$ & Secondary & $\begin{array}{r}\text { school } \\
\text { certificate }\end{array}$ \\
\hline & & 3.61 & 3.69 & 3.54 & & 3.45 \\
\hline Postgraduate degree & 3.61 & - & 0.955 & 0.954 & & 0.710 \\
\hline BA degree & 3.69 & 0.955 & - & 0.497 & & $* 0.256$ \\
\hline Diploma degree & 3.54 & 0.954 & 0.497 & - & & 0.835 \\
\hline $\begin{array}{l}\text { Secondary school } \\
\text { certificate }\end{array}$ & 3.45 & 0.710 & 0.256 & 0.835 & & - \\
\hline
\end{tabular}

$(* *)$ : This sign means that the value is statistically significant at the statistical significance level is $(a \leq 0.05)$ Based on table 13, when conducting a comparison between the ones holding BA degree and the ones holding secondary school certificate, it can be noticed that the difference is for the favor of the ones holding BA degree. Conclusion:

It was found that the job satisfaction level of the selected administrators is moderate. It was found that there is a statistically significant difference -at the statistical significance level of ( $a \leq 0.05)$ - between the respondents' job satisfaction levels which can be attributed to gender and academic qualification. The gender-related difference is for the favor of females. It was found that there isn't any are statistically significant difference -at the statistical significance level of $(a \leq 0.05)$ - between the respondents' job satisfaction levels which can be attributed to experience.

\section{Recommendations}

In the light of the study's results, the researchers recommend:

1) Exerting more effort to promote job satisfaction among the staff working at kindergartens. Such effort should be exerted by the Jordanian Ministry of Education. Such effort may include conducting studies about the social, economic, and psychological problems experienced by those administrators.

2) Improving the moral and financial incentives systems of the staff working at kindergartens. The researchers recommend rewarding the employees who show distinguished performance at kindergartens. They recommend appreciating the employees who exert much effort at kindergartens.

3) Acquiring the latest technologies by kindergarten administration. The researchers recommend engaging administrators in the decision making process and developing their capabilities. They recommend providing employees with training courses.

\section{References}

The Ministry of Education (2018)

Abu Taleb, T. (2000). Reasons behind experiencing work stress by kindergarten teachers in Greater Amman region. Dirasat Journal. 27(1).187.

Al-Harahsheh, M. and Ahmad, A. (2013). The problems facing the administration of the kindergartens in Mafraq, Jordan from the perspective of the female employees. The Academia Journal of Social and Human Studies (AJSHS). 1(9).107

Al-Sharayri, K. (2007). The reality of kindergartens in the Hashemite Kingdom of Jordan. Journal of the Association of Arab Universities for Education and Psychology. 5(2).1

Sawalha, M. (2006). Job satisfaction of female kindergarten teachers in Jordan in accordance with some variables. The Journal of Educational and Psychological Sciences. 7(2). 112 
Al-Taweel, H. (2006). Educational administration: concepts and prospects. Amman. Wa'el publication and distribution house.

E'laimat, A. and Aqil, M. (2014). The job satisfaction of the female teachers in public kindergartens in the central province in Jordan from the perspective of those teachers. Al-Manarah Journal for Research and Studies. 20(2). 267.

Al-Anzi, S. (2009). The job satisfaction of the female teachers in the kindergartens in the Kingdom of Saudi Arabia. Unpublished MA thesis, Yarmouk University, Jordan

Al-Habet, A. (2013). Job satisfaction of female teachers in public and private kindergartens. Arab Studies in Education and Psychology. 3(43).122

Hamshari, O. (2010). Modern management of libraries. Amman. Safa' publication and distribution house.

Haybah, Z. (2016). Job satisfaction of female kindergarten teachers in Al-Madeene Al-Munwarah. Arab Studies in Education and Psychology. 6(79), 409

Bogler, C, and Ronit, G (2001). Reasons of the behavior of principals as a multiple, American Educational Researcher Association, Quebc, Canada.

Jiang, Y (2005). The Influencing and Effective model of early childhood: Teachers. Job satisfaction in china, US - China Educational Review, 2(11), 65-74.

Acknowledgement:

The researchers would like to thank the respondents who participated in the present study. 